Article

\title{
Sustainable Water Management in the Tourism Economy: Linking the Mediterranean's Traditional Rainwater Cisterns to Modern Needs
}

\author{
Jared Enriquez ${ }^{1}$ (D), David C. Tipping ${ }^{2}$, Jung-Ju Lee ${ }^{3}$, Abhinav Vijay ${ }^{4}$, Laura Kenny ${ }^{1}$, \\ Susan Chen ${ }^{5}$, Nikolaos Mainas ${ }^{6}$, Gail Holst-Warhaft ${ }^{7, *}$ and Tammo S. Steenhuis ${ }^{4}$ \\ 1 Department of City and Regional Planning, Cornell University, Ithaca, NY 14853, USA; \\ jre92@cornell.edu (J.E.); lek224@cornell.edu(L.K.) \\ 2 Cornell Institute for Public Affairs, Cornell University, Ithaca, NY 14853, USA; david.tipping@hotmail.com \\ 3 College of Arts and Sciences, Cornell University, Ithaca, NY 14853, USA; j12566@cornell.edu \\ 4 Department of Biological and Environmental Engineering, Cornell University, Ithaca, NY 14853; \\ anv7@cornell.edu (A.V.); tammo@cornell.edu (T.S.S.) \\ 5 Department of Operations Research, Cornell University, Ithaca, NY 14853, USA; wsc47@cornell.edu \\ 6 Water and Sewage Authority of Thira, Thira, Santorini 84700, Greece; nikmainas@gmail.com \\ 7 Cornell Institute for European Studies, Atkinson Center for a Sustainable Future, Cornell \\ University, Ithaca, NY 14853, USA \\ * Correspondence: glh3@cornell.edu; Tel.: +1-607-227-9570
}

Received: 10 August 2017; Accepted: 4 November 2017; Published: 8 November 2017

\begin{abstract}
Communities on islands with mass-tourism, like Santorini, rely on vast quantities of water to develop the local economy. Today's inhabitants of Santorini have largely abandoned the traditional cisterns that were used to sustain the island's pre-modern civilizations in favor of water obtained from desalinization, ship deliveries, and well withdrawals. In June 2016, Cornell University researchers worked with the Water and Sewage Authority of Thera (DEYATH) to assess the viability of improving sustainability and water efficiency by restoring traditional rainwater harvesting and storage cisterns. The team surveyed five cisterns, held meetings with water authority staff and mayoral leadership, conducted interviews with local tourism stakeholders, and coordinated with Global Water Partnership-Mediterranean. One conclusion was that cisterns could be rehabilitated as decentralized storage reservoirs and integrated into the island's centralized water systems, or alternatively, serve as educational and cultural spaces used to communicate the importance of water to residents and tourists. The research findings highlight how multi-stakeholder partnerships could assist local authorities with developing new water management initiatives to foster more sustainable models of tourism development.
\end{abstract}

Keywords: water security; sustainable tourism; human ecology; heritage values; rainwater harvesting; Greece; ancient water supply systems; ecotourism; conservation; climate adaptation

\section{Introduction}

Local governments and resource managers in Mediterranean nations must adapt new water management practices to mitigate the effects of the increased precipitation variability associated with climate change and current unsustainable water management. Usually, climate and growth-management policies are adopted after identifying the threats impacting public water supplies and services. However, areas without significant population growth often fail to enact the resource management policies necessary for adapting to current and future water supply risks. Santorini, an island in the Cyclades, exemplifies how Mediterranean islands without significant population growth must still develop integrated approaches to water governance. This paper explores the 
traditional legacy of rainwater cisterns that previous generations operated to create a resilient community-based model of water management. It explains how development of the tourism sector threatens water security, and how cistern preservation might foster a more sustainable model of heritage tourism. After presenting our research methods and discussing the feasibility of rehabilitating traditional water cisterns to collect rainwater, we propose several cost-effective strategies for assisting water utilities in reshaping local behaviors and attitudes towards more sustainable tourism and natural resource management. We argue that on Mediterranean islands, water utilities grappling with meeting the demands of mass-tourism, exogenous political and financial pressures, and climate change could learn much from historical practices of water management.

\subsection{Local History of Water Management in the Mediterranean}

The Aegean island of Santorini is reported to have been first settled around the fourth millennium BC, in the Neolithic period. Mays documented that Neolithic populations (5700-3200 BC) were the first to successfully modify the environment for the purpose of controlling the flow of water for flood protection and irrigated agriculture. In contrast to other civilizations of the day, whose communities established settlements in proximity to large rivers that offered seasonal/permanent sources of water supply (Egyptians, Sumerians), the Minoan people, centered on Crete and Santorini during the Bronze Age (3200-1100 BC), instead settled in arid regions [1].

The archaeological record reflects that the Minoan civilization initially survived and then flourished, creating influential and wealthy settlements. The Minoans constructed housing complexes and later palaces, using advanced technologies for the collection, transport, and storage of water. On Crete, the various technologies used included: rainwater harvesting, aqueducts, underground water storage cisterns, distribution systems, gutters, channels and pipes, sedimentation basins, and filtration, as well as drains and sewers [2,3]. Furthermore, advanced hydraulic structures, including large stone conduits with branches and terracotta pipes, enabled the supply of freshwater across the area of civilization [4]. Table 1 specifies the location of the earliest ancient water technologies that allowed the Minoan civilization to flourish, though a complete picture of the achievements of Minoan civilization on Santorini remains unknown due to a volcanic eruption that buried the island in a thick layer of tephra sometime between $1650 \mathrm{BC}$ and $1600 \mathrm{BC}$.

Periodic water shortages, associated by some researchers with climate change, forced the Minoan people to create and innovate with water technologies and manage water in a more efficient manner [5]. The Minoans were a seafaring people, establishing a port settlement at Akrotiri on the southeast coast of Santorini. As a trading hub, this port appears to have played an important role in establishing vast linkages between the people of the Mediterranean [6]. In order to survive, the Minoan civilization adapted to the water-poor environment in new ways, prioritizing small-scale storage, water safety, and ecological and environmental sustainability [7]. On Crete, the people initially drew water from wells, and later built small systems of dams. However, as they engaged in trade across the Mediterranean, the civilization gained influence, wealth, and sophistication. Innovation with water technologies appears to have begun with the collection and transportation of rainfall runoff. These ancient water technologies were developed to meet essential domestic and agricultural water requirements. On Santorini, Antoniou et al. [8] reported that the Minoans collected rainfall runoff from prepared surfaces, transported it in channels and pipes, and stored it in underground cisterns. As Tsionis et al. [9] make clear, Minoan civilization went into decline between the time of the Theran eruption and the mid-fifteenth century BCE, and though there is no consensus on the specific origins of decline, evidence suggests that decline was a gradual phenomenon. 
Table 1. Water technology developments of Ancient Minoa *.

\begin{tabular}{|c|c|c|}
\hline Technology & Location & Date \\
\hline Wells & $\begin{array}{c}\text { Not specified } \\
\text { Knossos Palace (six wells) }\end{array}$ & $\begin{array}{l}2900-2300 \text { BC } \\
1900-1700 \text { BC }\end{array}$ \\
\hline Aqueducts & $\begin{array}{l}\text { Tylissos (Spring of Agios Mamas) } \\
\text { Knossos Palace (Springs of } \\
\text { Mavrokolymbos }(500 \mathrm{~m}) \text {, Juctas } \\
(10 \mathrm{~km}), \text { Fundana }(15 \mathrm{~km}))\end{array}$ & $\begin{array}{l}2000-1100 \text { BC } \\
1900-1700 \text { BC }\end{array}$ \\
\hline \multicolumn{3}{|l|}{ Rain Harvesting Systems } \\
\hline $\begin{array}{l}\text { Flat rooftops and courtyard water } \\
\text { collection surfaces }\end{array}$ & $\begin{array}{l}\text { Not specified } \\
\text { Phaistos Palace }\end{array}$ & $\begin{array}{l}2900-2300 \text { BC } \\
2000-1900 \text { BC }\end{array}$ \\
\hline Gutters and channels & Not specified & $2900-2300 \mathrm{BC}$ \\
\hline Stepped Chute Channel & Knossos Palace & $1900-1700 \mathrm{BC}$ \\
\hline $\begin{array}{c}\text { Terracotta pipe } \\
\text { (round/spigot/water distribution) }\end{array}$ & Knossos Palace & 1900-1700 BC \\
\hline $\begin{array}{c}\text { Terracotta pipe } \\
\text { (rectangular/water transportation) }\end{array}$ & Myrtos and Pyrgos Palaces & $1700 \mathrm{BC}$ \\
\hline Sedimentation basins & $\begin{array}{c}\text { Tylissos } \\
\text { Knossos Palace }\end{array}$ & $\begin{array}{l}2000-1100 \text { BC } \\
1900-1700 \text { BC }\end{array}$ \\
\hline Filtration device (charcoal) & Tylissos & $2000-1100 \mathrm{BC}$ \\
\hline Filtration (coarse sand filters) & Knossos Palace & 1900-1700 BC \\
\hline Cisterns & $\begin{array}{l}\text { Chamaizi (housing complexes) } \\
\text { Phaistos Palace } \\
\text { Zakros Palace (7 m diameter/five } \\
\text { columns/step access) }\end{array}$ & $\begin{array}{c}3000-2000 \mathrm{BC} \\
2000-1900 \mathrm{BC} \\
1500 \mathrm{BC}\end{array}$ \\
\hline Toilets & $\begin{array}{c}\text { Phaistos Palace } \\
\text { Knossos Palace (wooden } \\
\text { seat/flushing conduit) }\end{array}$ & $\begin{array}{l}2000-1900 \mathrm{BC} \\
1900-1700 \mathrm{BC}\end{array}$ \\
\hline Sewers & Not specified & $3200-1900 \mathrm{BC}$ \\
\hline
\end{tabular}

\subsection{Technology and Governance in the Twentieth Century}

On Santorini and in other areas of the Mediterranean, the advent of mass tourism in the 1970s brought great wealth while placing severe stress on local water supplies. Today's tourists are mostly unaware of the continuous tradition of rainwater collection and storage in underground cisterns that lasted until recent decades. Traditionally, house construction incorporated at least one cistern, while multiple residences would also share a village cistern, which was constructed for additional water supply in periods where household cistern collection proved insufficient. Santorini shared the building customs of what Maliva and Missimer describe as "the Greek tradition" of emphasizing "a multiplicity of supply sources, each as a safeguard against the failure of others" [10]. Traditional water practices thus implemented a system of community-based management, where household owners would maintain both their own cisterns and those of the village. The conveniences of modern water technologies enabled residents to cease operating both their own household cisterns and those of the village. Several village cisterns remain in operation, but the extent to which they are maintained and utilized for non-potable water use varies considerably across the island. The remaining cisterns are preserved and maintained by water authority staff and demonstrate an original construction characterized by meticulous design and walls that are coated with a mixture of Theriac earth (a local light-colored, extremely porous volcanic rock or pumice) and lime, which creates a seal that is impermeable to water.

The expansion of public water services in the 20th Century and the adoption of desalinization technologies in the 21st Century meet the water demands of mass tourism. Though modern water practices have continued to improve, cisterns traditionally built to store rainwater have largely been abandoned. 
Instead of paying attention to the ancient water supply system that made the settlement of Santorini possible, visitors to the island are treated to swimming pools, jacuzzis, and an impression of abundant water (see Figure 1). They are not encouraged to conserve water, and many remain unaware of the ingenious technologies developed to manage water on the island from antiquity to the 20th century.

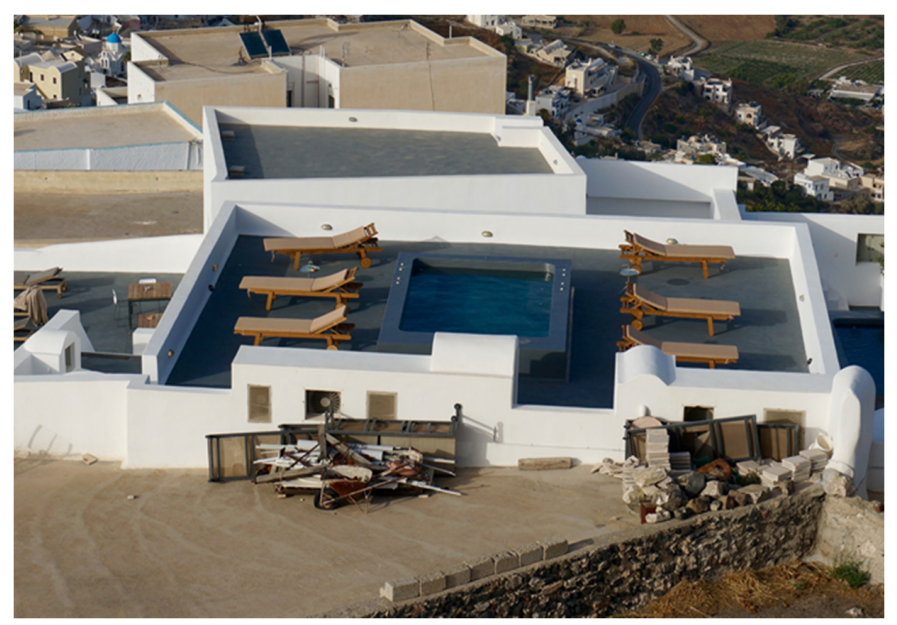

Figure 1. Example of rooftop water features, spaces in previous centuries that would serve as catchment areas for collecting rainwater into the household cistern.

\section{Materials and Methods}

\subsection{Site Description: The Island of Santorini}

Santorini's permanent population of an estimated 15,000 inhabitants swells to a daily average of 100,000 individuals with the arrival of tourists in the summer months [11,12]. Santorini is not endowed with substantial, permanent sources of water, and only one source of water, the Zwoס́xo $\Pi \eta \gamma \eta$, translated as the life-giving spring, remains accessible today. As Figure 2 shows, the summer months feature virtually no rainfall while tourism's peak period demands increase.

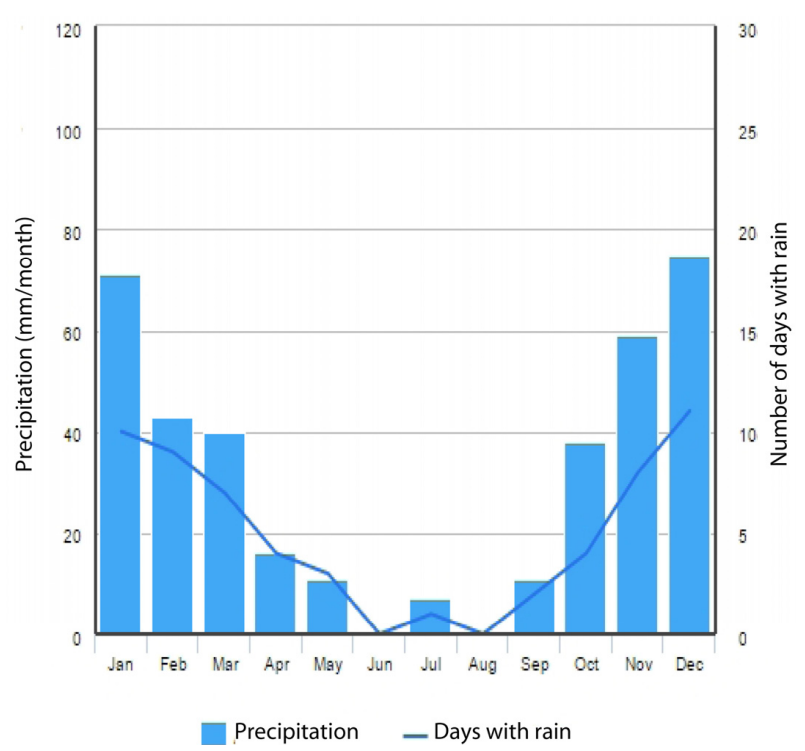

Figure 2. Annual distribution of rainfall for Santorini [13]. 


\subsection{Research Plan}

In 2016, Gail Holst-Warhaft, of Cornell University's Institute for European Studies, together with Global Water Partnership-Mediterranean and the Water and Sewerage Authority of Santorini, $\triangle E Y A \Theta$ (hereafter DEYATH), began developing a research project to promote rainwater harvesting on Santorini. The research was designed to help the island water authority improve water security by restoring public water cisterns that had fallen into disuse. Recognizing that rainwater collected in these storage reservoirs would be insufficient to meet total water demand during the dry summer, it was still considered important to repair and reuse them to provide additional water security. A secondary aim was to increase community awareness of the history of rainwater harvesting on Santorini, and highlight the potential of practical and low-cost household water storage.

In June 2016, funded by a grant from Cornell University's Atkinson Center for a Sustainable Future and Institute for European Studies, a multi-disciplinary research team travelled to Santorini to conduct research on rainwater harvesting. Team members comprising students, graduate students, and fellows from Engineering, City Planning, Operations Research, and Social Sciences were chosen because of the complex issues associated with integrated water resource management. At the project's start-up meeting, DEYATH informed the research team that it would be desirable to reuse the underground water storage cisterns to create additional water storage to ensure that increasing water demands could be met in dry seasons. The water authority discussed the merit of making the cisterns available for the storage of both rainwater and treated water from island desalination plants. By restoring unused rainwater cisterns, the Water Authority could augment their storage capacity and raise community awareness of the island's former sustainable management techniques.

The research team formulated a research framework recognizing that their objectives should reinforce the treatment of water as cultural capital, as established by Holst-Warhaft and Steenhuis in Losing Paradise [14]. Before undertaking field assessments, the team discussed sustainable rehabilitation options in the broader context of raising awareness of ancient water infrastructure among tourists. The Cornell team agreed that there was merit in repurposing at least one cistern for use as a water history museum, since the preservation of a site would provide information to both residents and tourists on rainwater harvesting, sustainability, and the value of water more generally. Further, the museum could be incorporated into a water hiking trail and factored into a communication strategy to raise public awareness about water conservation and sustainability.

\subsection{Fieldwork}

The field work comprised four tasks, centered primarily on five cisterns (see Figure 3). Aside from the Byzantine cistern at Panagia Episkopi (constructed circa 1115), four of the cisterns the team investigated were constructed in the 20th Century. The first task entailed field investigations to inspect, map, and assess the condition of the five existing cisterns, and to develop information the Municipality of Thera could use to decide if any cistern should be rehabilitated. This component included the development of a cistern assessment protocol and photographing the cisterns. Given the limited time available, the team was unable to conduct extensive research on the condition of the cisterns, but the team agreed that any further assessment should include structural factors, such as the integrity of the strata and lined surfaces, historical and ownership information, the calculation of site dimensions, and risk analyses for rehabilitation. Ideally, this assessment could lead to a plan for the funding of a municipal water storage capacity enhancement project, contingent on the feasibility of rehabilitating and/or expanding the capacity of cisterns, and integrating these into the island's water supply systems.

The second task explored the possibility of establishing a water museum and developing plans for both physical exhibits as well as a virtual project. Cornell team members took panoramic photographs of the Panagia Episkopi Church cistern so that the cistern could be incorporated into Civiltà dell'Acqua and UNESCO's Global Network of Water Museums. This component included community engagement and the development of ideas that the Municipality could consider for funding and implementing. As the only remaining Byzantine church on the island, Panagia Episkopi in Mesa Gonia is a spectacular 
site. The team documented the impressive underground cistern on the site, which was reportedly constructed in the 11th century when the church was built. An illustration of the Byzantine Church cistern interior is provided in Figure 4 below. Ancient stones incorporated in the cistern and the church indicate it was partly built with spolia or fragments from the ruins of Ancient Thera located nearby. The team photographed the church, courtyard, and cistern, to accompany the description of the site on the project website, which is currently incomplete but will shortly be available.
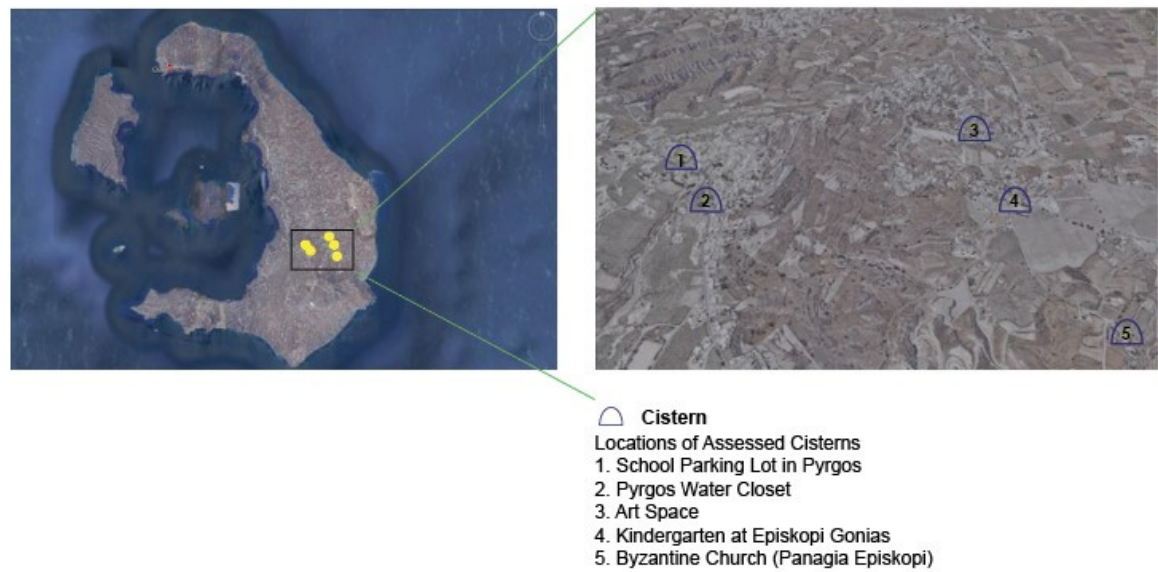

Figure 3. The centrally located cistern sites within Santorini.
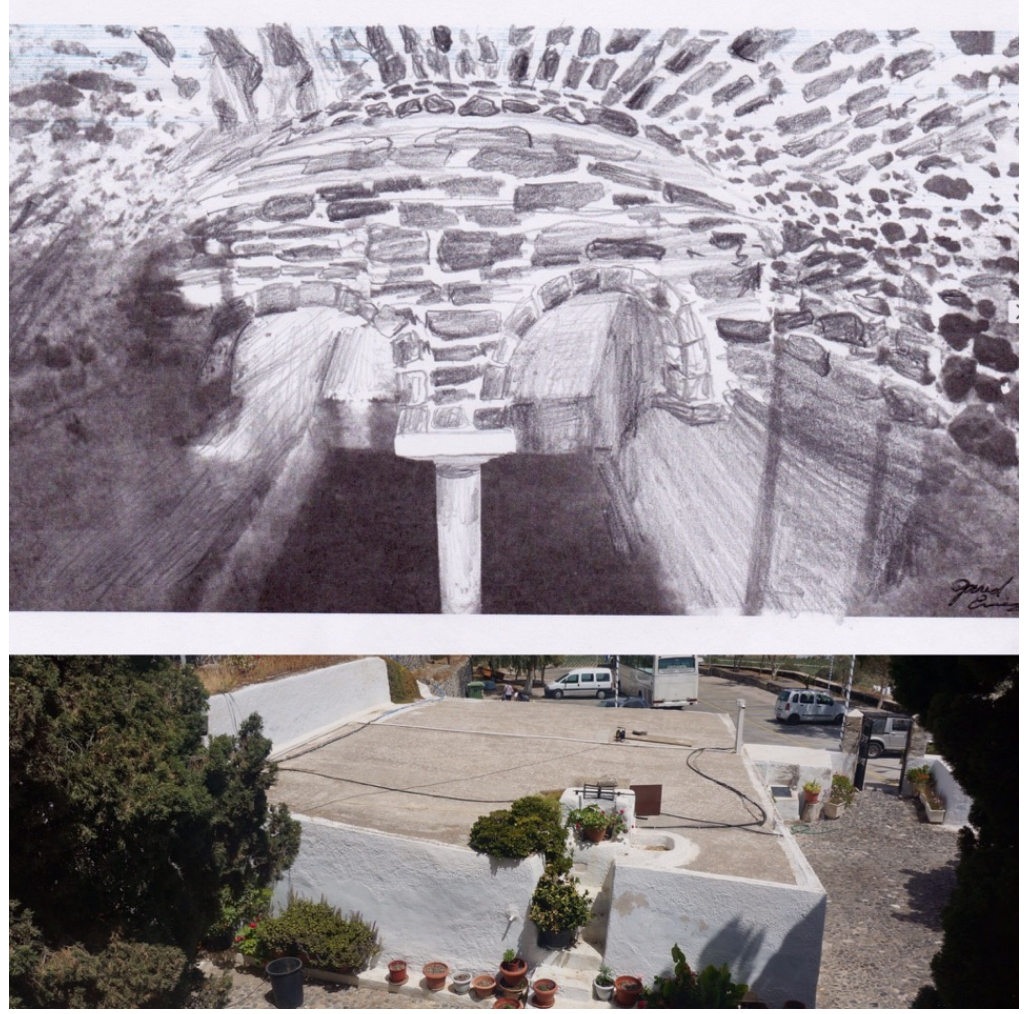

Figure 4. Interior (top) and well access (bottom) of the cistern at Panagia Episkopi. Illustration and photography by Jared Enriquez.

The third task involved the identification of water features and monuments on Santorini that could be mapped and signposted along a water hiking trail accessible to both local residents and visiting tourists. In the spring of 2017 , two members of the team returned to the island to document 
five water walks on a map with explanatory keys that tourists could navigate (see Figure 5 below). The community could develop additional trails and signage, contingent on community support for the development of the project.

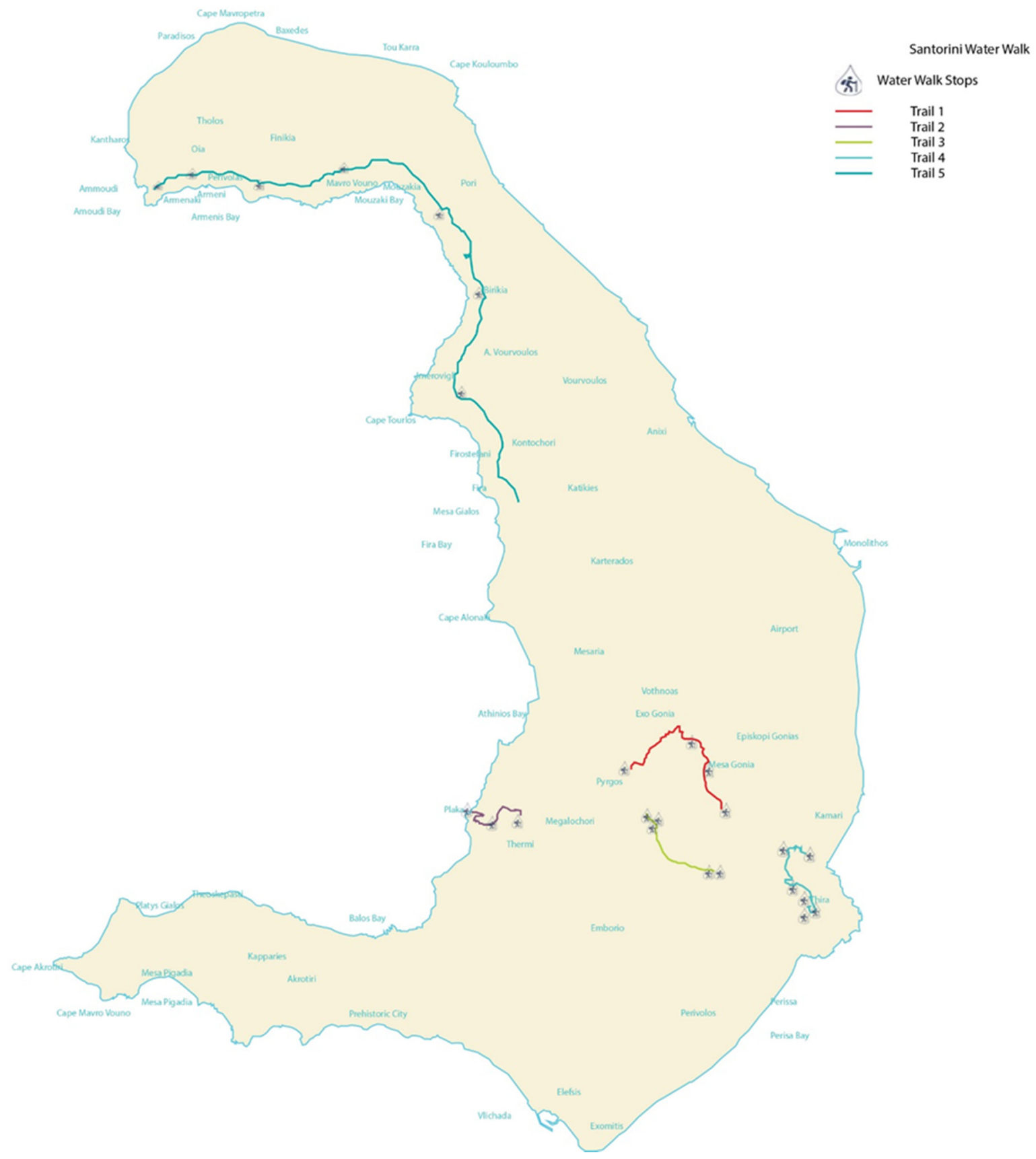

Figure 5. Map of proposed water walk stops and trails. Map prepared by Laura Kenny.

Our final task was the development of a communications strategy to inform the Municipality about how to promote an ethos of valuing water and supporting water conservation and sustainability. It was also aimed at informing visitors to the island about the need to conserve water. In order to assess the likelihood of local support for water efficiency measures, team members conducted unstructured and semi-structured interviews with diverse community stakeholders and key informants, including hotel owners, doctors, hotel managers, restaurant and service industry staff, wine store owners, a tour guide, and residents in Exo Gonia 
and Mesa Gonia. A more detailed account of the team's strategy for informing locals and tourists about the need to conserve water is outlined in the discussion section below.

\section{Results}

\subsection{Cisterns}

Working with the water authority, the team helped to document the dimensions of the five water cisterns and assess their condition for possible rehabilitation as municipal water storage or as water monuments. During information gathering to calculate a water balance, it was estimated that at most one percent of rainfall on the island could be captured in cisterns today. The estimate was based on the assumption that a household of four has a storage tank of maximal $50 \mathrm{~m}^{3}$ [15]. This, with a population density of 200 people $/ \mathrm{km}^{2}$, gives a total maximum tank available storage of $2500 \mathrm{~m}^{3} \mathrm{~km}^{-2}$. Assuming that the tanks are filled once per year, the storage represents less than $0.7 \%$ of the rainfall of the $370 \mathrm{~mm} \mathrm{y}^{-1}$ (equivalent to $370,000 \mathrm{~m}^{3} \mathrm{~km}^{-2} \mathrm{y}^{-1}$ ).

\subsection{Typology of Cistern Use}

In order for the Municipality to consider potential opportunities to reuse and/or repurpose individual cisterns across the island, the Cornell team created a typology of cistern uses for Santorini. This could be used by DEYATH to assess and model preferred options and potential configuration requirements for cisterns, and to assist with the determination of the feasibility of rehabilitation projects. Table 2 presents five potential future uses of cisterns on Santorini.

Table 2. Proposed Typology of Cistern Use.

\begin{tabular}{cc}
\hline Number & Use/Reuse Type \\
\hline 1 & Storage of harvested rainwater \\
2 & Storage of desalinated water \\
3 & Storage of well water \\
4 & Storage of water from all sources \\
5 & Conversion into a cultural facility (e.g., a museum) \\
\hline
\end{tabular}

\subsection{Feasibility of Rehabilitating Public Cisterns}

After an initial assessment, all five cisterns were deemed to be in sufficiently good order to be repaired and reused for storage or repurposed as water monuments, such as reconfiguring the Pyrgos water closet cistern illustrated in Figure 6 as a museum. In addition to the general assessments, volumetric capacities were calculated to support the water board's determinations as to which cisterns should be rehabilitated for additional water storage, with the results listed in Table 3.

Table 3. Cistern Water Storage Capacity Data.

\begin{tabular}{cccc}
\hline Cistern & Date & Estimated Capacity (L) & Rehabilitation Determination \\
\hline Panagia Episkopi Church & circa 1115 & Unknown * & Water monument and continued \\
operation by church \\
Pyrgos Public Carpark & circa 1952 & 298,000 & Storage \\
Pyrgos Water Closet & circa 1952 & 283,000 & Storage and museum \\
Mesa Gonia Kindergarten & Unknown & 120,000 & Storage \\
Mesa Gonia Art Space & Unknown & 439,000 & Storage and cultural facility \\
\hline
\end{tabular}

Note: * could not be determined due to inability to obtain an accurate measurement of depth. 

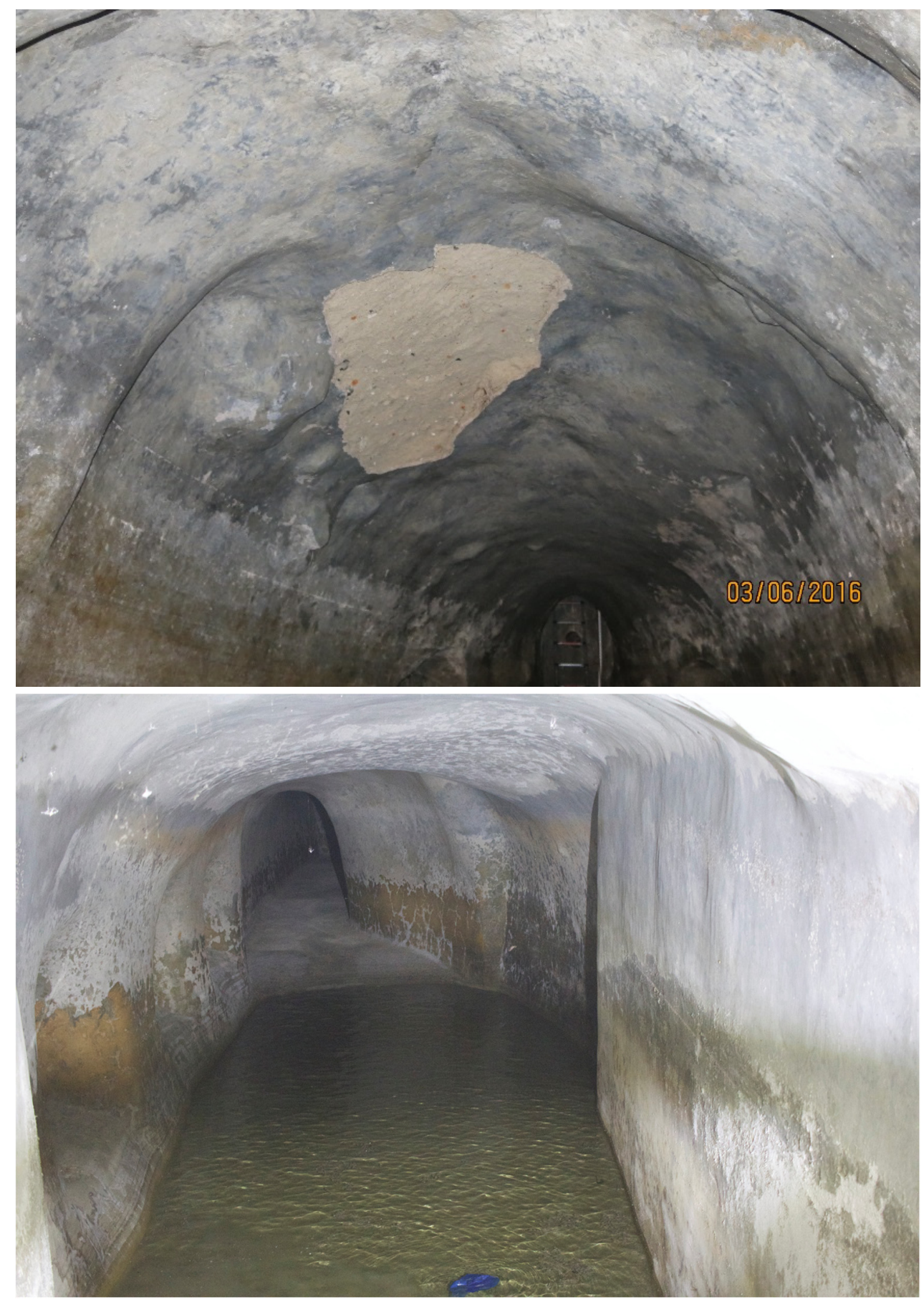

Figure 6. Damaged section of liner inside the water closet cistern in Pyrgos (top). Structurally sound conditions at the Exo Gonia cistern near Art Space (bottom). Photos taken by Nikos Mainas.

\subsection{The Virtual Water Museum}

After assessing all five cisterns, the team confirmed that Panagia Episkopi would be an ideal site for both an actual water monument and a virtual museum. The team proposed making the cistern more accessible to visitors by the use of windows and an extended viewing platform. Based on the previous collaboration of Gail Holst-Warhaft with Dr Eriberto Eulisse, Director of the non-governmental organization (NGO) Civiltà dell'Acqua, in Venice, the Venice office of UNESCO has decided to designate the Byzantine Church in Santorini as a UNESCO Global Network of Water 
Museums site. The international network of virtual water museums was launched in 2017 [16]. The team recommended that the cistern be made visible to church visitors by the insertion of a glass viewing panel in a section of the side wall above the waterline or by the installation of an easily accessible viewing platform.

\subsection{Water Walks}

As mentioned above, a water walk map was completed in the Spring of 2017 (see Figure 3). Signage in English was developed, and it was proposed to the municipal authorities to transfer this to some sort of durable material, as is currently done with archeological signs on the island. The walks connect both symbolically and physically to the trails that have now been included as part of the UNESCO Global Network of Water Museums.

\section{Discussion}

The problem of water scarcity is not unique to Santorini, nor is the current interest in supplementing imported water and desalinated water with the older technology of collecting rainwater in the Mediterranean. Malta, for example, has adopted a new water development plan that includes subsidies for the installation of tanks. Cyprus, with a permanent population of over 1 million, began offering subsidies for rainwater harvesting and other water conservation measures in 1997. By 2010, the nation granted a total of 13,172 subsidies at the cost of 5.5 million Euros [17].

In Ancient Greece, residents were mandated by law to maintain their household and community cisterns, as is evident from the law of the Astynomoi at Pergamon [18]. The documentation of fines would provide evidence of the extent to which municipalities monitored and enforced cistern maintenance, as the Astynomoi required updates to the registry of cisterns. Millenia later, rainwater harvesting remains mandatory for the water-scarce islands in Greece [19]. All new buildings on Aegean islands must have rainwater collection tanks, the size of which is determined by the structure to which they are attached. Currently, there are no subsidies in place to help defray the cost of the tanks.

Water security and sustainable growth now require community and business stakeholders to engage with governments to forge a shared sense of ownership and accountability for the environment. On Santorini, this will require new water management policies and forward-cost water conservation and efficiency measures. The water authority recognizes the problem, though few reforms have been instituted. New interest in the rehabilitation of public cisterns and their potential integration with the centralized water supply systems indicates a readiness to explore more sustainable ways of delivering water, such as storing rainwater during the off season and using it to meet the high demand generated in the peak tourist season.

\subsection{Sustainable Tourism and Water Security}

Water security is essential to sustainable development, yet many factors exacerbate water scarcity and stress across the Cyclades Islands, especially tourism and climate change. The approach of the local authorities has been to respond to immediate crises by constructing additional desalination plants and importing water. However, in addressing long-term water scarcity, preventative measures and strategic planning might be more effective. According to the UN Water Analytical Brief of 2013, "good governance is essential in achieving water security" and "well-designed and empowered institutions with supporting legislative security and policy instruments" are required [20]. Local water authorities will face increasingly more complex water supply challenges in attempting to meet the rapidly increasing demands that tourism already exerts on the natural environment.

Tourism is the mainstay of the Santorini economy, though agriculture, especially viticulture, is an active economic sector for the island. The permanent population of an estimated 15,000 inhabitants swells to a daily average of 100,000 with the arrival of tourists in the summer months. The Water and Sewage Authority of Thera (DEYATH) has collected data confirming that Santorini is experiencing widespread water shortage [21]. The volume of water supplied in 2015 met only around 63\% 
of total water demand. While large volumes of water have been extracted from the island's groundwater aquifer using highly efficient pumps in recent times, this water source has, in varying degrees, become increasingly brackish. The costs of the overexploitation of groundwater resources and the importation of freshwater from the mainland of Greece [22] are born by the permanent inhabitants of the island and transferred back to the tourism industry in the form of high water costs and environmental damage by both greenhouse gas emissions and the burdening of the marine environment with salty discharge [23].

Water demand from the tourism industry is increasing. Data from the Civil Aviation Authority and the consulting firm HVS confirm that the number of tourists visiting Santorini has increased by approximately $60 \%$ over the past 10 years, with tourism arrivals expected to continue a growth trajectory into the future [24]. Segmentation of the hotel industry indicates significant growth in various hotel categories, particularly those at the higher end of the market. In contrast to other classes of hotel rooms and beds, the number of both high-end rooms and beds has grown by more than $200 \%$ since 2006. Since higher-end hotels often operate water features such as pools and jacuzzis, luxury hotels usually consume larger volumes of energy and water. Future research should measure the differences in both water and energy usage for luxury versus more affordable hotels and villas on a per capita basis.

Despite the long-term costs of continuing the present strategies of water management, local economic interests that benefit from the tourist industry have ignored the opportunity of instituting more sustainable water management practices and solutions, such as water-saving signage and sustainability incentives. It is possible that business owners fear such measures would prove disruptive to the development of the island's key industry. By remaining wedded to assumptions that their water withdrawal has a minimal impact on the natural environment, and trusting that additional desalinization plants can fill any gaps in water demand, Santorini's tourism model may already be outmoded. There is growing demand for environmentally conscious and socially responsible travel that emphasizes economic benefits to host communities, the minimization of negative impacts of tourism, and the preservation of cultural and natural resources. Further, as eco-conscious millennials constitute a larger share of visitors, they will dramatically reshape consumption patterns and consumer decisions [25]. Rising demand for destinations that are rich in art, historic and cultural heritage, natural beauty, and spirituality are becoming foundational factors for the economic competitiveness of tourism destinations. Ecological preservation and the cultural authenticity of the locale are recognized as closely linked to the richness of experience underpinning modern tourism (e.g., ecotourism, geo-tourism, pro-poor tourism, cultural tourism, responsible tourism, sustainable tourism, etc.) [26]. As a consequence of changing market forces, successful and sustainable tourism now requires greater community input and the incorporation of local values, cultures, and traditions. This is all the more important given prevailing forms of economic growth, as local populations are usually the first to bear the brunt of water inequity that can result in shortages of clean and safe water for domestic consumption [27].

The sustainability and quality of water resources relies on community retention of public water services. Public water supplies and services are contingent upon high quality standards, affordable and reliable infrastructure systems, appropriate pricing, and the management of supply and demand on a sustainable basis. To ensure affordability and quality, Santorini must value water as a local public good [28].

\subsection{Local Responses to the Impacts of Mass Tourism}

To meet the increasing demand for water during the tourist season, local government officials have approved high capital expenditures to construct and operate six desalination plants. This water meets the immediate needs of the tourist industry, but according to DEYATH and a subset of community stakeholders with whom the team engaged, local residents on Santorini remain skeptical of the safety and flavor of desalinated water. Despite reassurances from the water authority that the water is safe, inhabitants of the island primarily drink bottled water. Amongst other factors, previous studies have identified taste and odor, risk perception, and personal familiarity with specific drinking water options as all influencing local willingness to consume desalinated water $[29,30]$. If the local population 
is expected to change their behavior and adapt to the consumption of desalinated water, a public awareness campaign may be necessary.

There are many arid areas where locals who are reliant on desalination choose to pay the higher cost of importing bottled water. These include several nations of the Middle East (Bahrain, Kuwait, Oman, Qatar, Saudi Arabia, and the United Arab Emirates) [31]. Cultural factors and values can sometimes overcome the negative perception associated with consuming desalinated water. Studies in Australia report that approximately $45 \%$ of survey respondents stated they would have no problem drinking desalinated water if available. However, around $12 \%$ of respondents had negative views, as this subset was mostly concerned with the perceived environmental damage desalination technologies could cause, in particular, increased greenhouse gas emissions and brine disposal in the marine environment [32].

\subsection{Water Extraction from Island Wells}

While DEYATH was able to provide limited information on the operation of the island's desalination plants, relevant information on water supplied from local well points is relatively unknown. To gain a better understanding of the function of public water supply from wells, the team made field visits to two sites. At the first well, the team observed a water tanker arrive to extract water, though it departed as the driver noted the ongoing fieldwork. It was not clear if this was a privately owned vehicle. At the second well, the team observed that the well-head apparatus did not appear to be fixed securely, suggesting an inadequate protection of the public water supply wells from sources of contamination.

These findings indicate a need for an improved governance of water in a context of uncontrolled water withdrawal, losses of potential water revenue, and the potential contamination of public drinking water sources. From the water utility perspective, core factors that need to be considered include maximizing water safety and minimizing revenue loss [33]. As there are multiple private water supply companies on the island, the water authority needs more accurate means to document the number of water tanker movements and the volume of bulk water being withdrawn and sold to hotels and other establishments.

Current rates of water withdrawals conflict with the UN's Sustainable Development Goals (SDGs). DEYATH reported that the volume of water extracted from the island aquifer in 2015 was $918,000 \mathrm{~m}^{3}$, though this rate of extraction does not seem to be feasible. In 2004, Mantoglou and Giannoupoulos estimated that the sustainable annual yield for Santorini was only $700,000 \mathrm{~m}^{3}$ [34]. As a result, the team noted that current water supply operations appeared to be placing the island aquifer at heightened risk of further saline intrusion and advanced degradation of water quality. This could promote health risks for some residents, as well as increase consumer and producer costs for water treatment.

\subsection{Potential Solutions}

The identification and uptake of best practices in water supply could inspire incremental improvements of integrated water resources management across Santorini and other sites in the Mediterranean. Santorini shares with other islands, such as Crete, Malta, and Cyprus, the need for the development of new infrastructure to meet the increasing annual water demand of millions of tourists.

Policies and strategies that simultaneously promote sustainability while fostering economic growth are needed. The challenge for local governments is knowing when to invest in developing, maintaining, and upgrading the water supply system, and how to promote water security for local populations at the lowest per unit cost. It is important for community leaders to wholly recognize the value of water in order to realize that investments in sustainability across all sectors of the economy can make good sense.

\subsubsection{Rainwater Harvesting}

A resumption of rainwater harvesting on Santorini has the potential to increase resilience and strengthen water security by providing another source of water that could be drawn on in the 
dry summer months. Even when untreated, the use of rainfall runoff can alleviate some stress on water resources by providing water for secondary/non-potable uses, such as gardening and flushing. Although collecting runoff from rooftop surfaces is simple, and often the most economical option for water supply, the water is of a lower quality than directly caught rainfall. On Santorini, plastic cisterns for household use are not too costly and could satisfy secondary/non- potable demand, especially during the rainy season. According to a 2006 report by Gratziou et al., the daily water use of Greek households was estimated to be $0.45 \mathrm{~m}^{3}$ or $450 \mathrm{~L}$ [35]. As the highest demand for water on Santorini occurs during the peak tourist season, which runs over the dry summer months, the storage of rainfall runoff during the winter and spring should be incentivized to help satisfy some of the demand. While there are also many types of plastic water tanks with around 10,000 L of capacity that can be purchased for less than 800 euros, it should always be remembered that Santorini's geological strata is ideal for the construction of large underground cisterns. Further, while 10,000 L capacity tanks have proven sufficient for getting through the dry season, Daniel A. Okun cautions that the reuse of reclaimed water for potable purposes may be feasible, but "imposes added public health risks that need to be accepted only as a last resort" [36].

While Santorini would not likely benefit from rainwater harvesting for flood risk mitigation, the potential for collecting and conserving more water cannot be understated. Regulations have been put in place to construct cisterns on 27 islands, mainly in the Cyclades and Dodecanese islands, though Santorini water authorities seem to be more concerned with the possibility of rehabilitating pre-existing cisterns. Given the preservation and cost-effective focus of the project, where five cisterns of local historical value were assessed for rehabilitation, the team did not propose specific institutional incentives or subsidies for constructing new cisterns, nor did the researchers examine the multi-purpose potential of cisterns outside of the conservation and collection motives expressed by DEYATH. The expansion of cisterns affording the direct potable reuse (DPR) of rainwater could lead to substantial reductions in the need for water withdrawals and imports in Santorini, as in other Mediterranean sites where water is scarce [37-39]. Furthermore, as Campisano et al. note, rainwater harvesting is now widely acknowledged as an acceptable source of non-potable water compared to other types of water reuse [40]. Hence, other water needs can be fulfilled to alleviate the water scarcity. While we strongly recommend that future researchers consider additional benefits that rainwater harvesting can provide to augment supply and storage, flood mitigation potential in Santorini is minimal because the runoff from torrential winter rains is transported rapidly through gullies into the sea. Moreover, according to the local people, floods have decreased in recent times. The historic development of settlements factored runoff into village design. In villages perched along cliffs, the traditional method of managing discharge diverts stormwater directly onto the streets and passageways that cascade into creeks called heimarra. These creekways double as passageways in the dry season and creeks in the wet season, functioning similarly to what modern populations would call a sustainable drainage system approach (SuDS). Slower runoff from these creekways usually supports the viticultural lands between the villages and the sea, while the torrential flows stream directly into the sea. These ingenious multi-functional corridors quickly reduce flood risks and afford local inhabitants the amenities of culturally distinctive pedestrian corridors in dry months and ecosystem services throughout the year.

\subsubsection{Raising Awareness}

The World Wildlife Federation in Greece has stressed the effect of mass tourism on Greece's water-scarce islands. The tourism sector in Greece uses a substantial amount of the nation's water resources. The concentration of tourists in water-stressed areas, such as the Aegean islands, and the fact that the number of tourists reaches its peak during the driest season, places additional pressure on water resources. Tourism and agriculture are by far the largest water consumers in Greece [41].

The purpose of the Santorini Water Walks (see map, Figure 5) was to heighten tourists' understanding of the limited water resources available on the island. Many tourists are unaware of the water conservation practices utilized in water-scarce regions, as well as the critical need of past 
generations to store water and protect its quality for use over the dry summer months. Interactions between locals and inquisitive visitors might also facilitate the transfer of local knowledge of proper cistern upkeep and heritage [42]. Santorini Water Walks follow present day and historic walking trails often frequented by tourists, with the aim of drawing the tourists' attention to water. On the Water Walks, one can see historic water infrastructure, such as cisterns and windmills, present day water infrastructure, such as desalinization plants, and natural features, such as the island's only significant spring and its saltwater baths. The walks also highlight the historic and present uses of water in farming and wine-making. By understanding the variety of ways scarce water has been managed on the island, as well as constraints to freshwater availability on the island, tourists may be inclined to conserve water while visiting Santorini, and take this knowledge back to their home countries. The Santorini Water Walks are intended to enable tourists to realize this goal, and participate in water conservation if they choose.

\subsubsection{Funding of Santorini's Water Conservation and Sustainability Initiatives through Tourism}

In discussions with the Municipality, water authority officials and community stakeholders stated that tourist industry operators appeared indifferent to environmental concerns. Internationally, there are many instances of market-based mechanisms being introduced to raise revenue for conservation and sustainability initiatives. The team first considered a simple mechanism, a tourism user fee (TUF). These are typically structured as an entrance fee, concession fee, license, or permit charge, or even tourism-based taxes. On Santorini, any user fee intended to incentivize conservation and sustainability activities would need to partially reflect the demand for scarce water resources. While entrance fees for archaeological sites are already utilized for cultural and historical preservation, a broader tourism-based tax than is already applied could be the most appropriate method for raising additional revenue. It would be levied on all hotel rooms. Alternatively, a separate departure tax could be collected at the airport and seaport and then allocated by DEYATH to water conservation and sustainability projects on a merit basis. To demonstrate the potential of a broader tourism-based tax, current data was used to project the amount of revenue that would have been raised in 2013. Noting that there were around 240,000 international airport arrivals on Santorini, and assuming a 3-5 Euro departure tax was levied, it is estimated that 720,000 to 1,200,000 euros could be generated annually. This level of funding could support significant investments in the planning and implementation of water conservation and sustainability initiatives. Furthermore, a portion of the revenue could be allocated to the hotels and restaurants to offer special incentives to operations that invest in advanced water technologies to improve their environmental performance.

If the municipality were to use the new revenue stream wisely, hotel and restaurant owners could be incentivized to make capital investments in sustainable development on Santorini. The island's hotel industry is characterized as dominated by local hotel operators, with few international hotel consortiums involved in the market. Revenue raised through user fees could lead to more effective stakeholder engagement, as well as increase the level of local support for the implementation of a TUF policy.

The team also considered the suitability of tax-exempt green bonds. These are fixed interest financial instruments. The State of Massachusetts and the World Bank have introduced green bonds in recent years to stimulate and coordinate public and private investments in ecologically sustainable development [43].

As the proposed rehabilitation programs would require capital expenditure, the municipality would need to determine if potential cistern reuse/repurposing works were feasible and acceptable. In addition, DEYATH would need to establish if the existing cistern storage capacity is optimal, or if any individual cistern would need to be increased in capacity to realize a net benefit. The range of issues identified for consideration include water quality and public safety, as well as integration with the centralized water system and overall resilience and water security. Given the complexity associated with considering options for the development of such a program, the team determined that DEYATH 
would need to prepare detailed business cases to support planning activities and decision-making on the rehabilitation of any particular cistern.

\subsubsection{Enforcement of Public Well Extraction Restrictions}

The data on water supplied from public water supply wells needs to be checked and calculations verified, so DEYATH should conduct a study to confirm the volume and rate of water extraction from each well on the island. In addition to a governance requirement to monitor the level of the water table and the quality of drinking water into the future, the water authority may want to consider regulating groundwater extraction and improving the protection of water sources on the island, which would necessarily include a program for wellhead protection. DEYATH needs to determine if there is a requirement to limit water withdrawals at any individual well-point, promote aquifer recharge with treated storm-water to improve aquifer function and restore groundwater quality, and in conjunction with potential improvements to the centralized water system, strengthen water security more broadly. The municipality may need to conduct an audit on the number of water tanker companies and the methods used to transport water to ensure consumers on the island are adequately protected. In addition to estimating potential revenue, by collecting accurate data DEYATH would be able to develop the necessary information to support advanced infrastructure planning for growth.

The DEYATH infrastructure requirement is defined as a cost effective and sustainable water supply system. The team identified four reasons that justify the development of a project to provide additional collection and storage of water for the island:

a. Taking pressure off the island aquifer;

b. Delivering water of improved quality for drinking, cooking, and personal hygiene;

c. Increasing water availability for domestic and productive purposes; and

d. Leveraging historical water achievements to promote a regional ethos of conservation and sustainability that values water and its life-giving properties.

The operating cost of the six desalination plants on Santorini is significant, as it requires a substantial input of energy, despite the introduction of a more energy-efficient process of reverse osmosis, such as the recent installation of a plant by TEMAK using this process [44]. At the water-energy nexus, the Water Authority should adopt a more sustainable approach to water security. Unlike Malta, Cyprus, or other Mediterranean tourist destinations, the local community seems particularly resistant to implementing water conservation and efficiency measures. The island community adapted to a modern water supply infrastructure very quickly following the installation of a centralized water supply service. Many households simply abandoned the practice of capturing rainwater and storing it in cisterns.

\section{Conclusions}

Ancient societies in the Mediterranean region have left human civilization lasting lessons for water management and the integration of infrastructure into the natural environment. While there is little known about the ancient legal and institutional arrangements put in place, the nature of Santorini's historical water collection, transport, and storage infrastructure suggests that these arrangements were very sophisticated. Santorini's tourist industry is well-situated to mitigate the risks of excessive water consumption driven by the current demands of the modern tourist. Preserving traditional cisterns, which are in disuse throughout the island, and enhancing water storage capacity could form part of a comprehensive and sustainable cultural, economic, and environmental solution.

Reinstating the use of cisterns at the household and community levels could appeal to the business and political actors invested in the tourism economy who might more easily endorse supplemental water storage solutions than adopt restrictive conservation mandates. Given the political and social challenges associated with adopting water conservation measures in a tourism economy, we recommend that Greek water authorities continue to expand engagement with multi-stakeholder 
partnerships to promote innovations in water management and foster more sustainable models of tourism. Academic and non-governmental organizations can study the island's water security challenges, such as undocumented groundwater withdrawals, without compromising personal or working relationships in the ways that locals might not wish to risk. Furthermore, the tourism industry's current reliance on water desalination plants and unconstrained water withdrawals from the island aquifer may not be financially or ecologically sustainable. The introduction of eco-tourism, the appreciation and revival of the island's traditional water management approaches, and strong local leadership among water authority officials, could help rectify years of excessive water use and prepare the community for future climate changes.

Acknowledgments: The team would like to thank first the people who helped us on Santorini, particularly the Mayor of Santorini, Nikolaos Zorzos, for his cooperation, hospitality, and assistance in the project. We are very grateful to Mainas' colleagues in the Thera Water and Sewage authority $(\triangle E Y A \Theta)$. We would also like to thank Irini Koch, who was instrumental in convening all partners. We also extend gratitude to our partners based outside of Santorini. In Athens, Global Water Partnership-Mediterranean supported us in the original design of the project. Konstantina Toli, and her colleague Mariela Antonakopoulou, worked with the team to establish a basis for our research. The team is grateful to Cornell's Atkinson Center for a Sustainable Future, who, together with the Institute for European Studies of Cornell's Einaudi Center for International Studies, funded our research. David Tipping wishes to thank George Tsitsas and Mariana Garstea who helped with project cost estimates, and Curtis Cude, International Water and Health Consultant, who reviewed a draft of this paper. Lastly, we acknowledge the assistance of the four very knowledgeable but anonymous reviewers in clearing up the many ambiguities in the originally submitted manuscript.

Author Contributions: Each author conducted the site assessments and contributed substantially to data collection. Jared Enriquez wrote and edited text in each section of the paper, created context maps and visual references, reviewed multiple drafts, and coordinated authorship contributions. David Tipping conducted the technical analysis and prepared the planning report, prepared the initial outline draft of this article, and provided feedback on multiple drafts of this paper. Gail Holst-Warhaft and Tammo S. Steenhuis conceived of the project, and as lead advisers substantially contributed to each phase of the project including this paper. Abhinav Vijay and Susan Chen co-authored the original section on tourism data. Jung-Ju Lee wrote most of the sections pertaining to communications strategies and tourism, and Laura Kenny produced the water map and authored the section on the Water Walks. Nikolaos Mainas assisted with data collection and site assessments, confirming many of the technical details of the project.

Conflicts of Interest: The authors declare no conflict of interest. The founding sponsors had no role in the design of the study; in the collection, analyses, or interpretation of data; in the writing of the manuscript, and in the decision to publish the results.

\section{References}

1. Mays, L.W. A Brief History of Water Technology during Antiquity: Before the Romans, Chapter 1. In Ancient Water Technologies; Springer Science and Business Media B.V.: New York, NY, USA, 2010.

2. Mays, L.; Antoniou, G.P.; Angelakis, A.N. History of Water Cisterns: Legacies and Lessons. Water 2013, 5, 1916-1940. [CrossRef]

3. Angelakis, A.N.; Koutsoyiannis, D.; Tchobanoglous, G. Urban wastewater and stormwater technologies in ancient Greece. Water Res. 2005, 39, 210-220. [CrossRef] [PubMed]

4. Angelakis, A.N. Evolution of rainwater harvesting and Use in Crete, Hellas through the Millennia. Water Sci. Technol. Water Supply 2016. [CrossRef]

5. Betancourt, P.P. The Dams and Water Management Systems of Minoan Pseira; INSTAP Academic Press: Philadelphia, PA, USA, 2012.

6. Angelakis, A.N.; De Feo, G.; Laureano, P.; Zourou, A. Minoan and Etruscan Hydro-Technologies. Water 2013, 5, 972-987. [CrossRef]

7. Yannopoulos, S.; Antoniou, G.; Kaiafa-Saropoulou, M.; Angelakis, A.N. Historical development of rainwater harvesting and use in Hellas: A preliminary review. Water Sci. Technol. Water Supply 2016. [CrossRef]

8. Antoniou, G.; Kathijotes, N.; Spyridakis, D.S.; Angelakis, A.N. Historical development of technologies for water resources management and rainwater harvesting in the Hellenic civilizations. Int. J. Water Resour. Dev. 2014, 30, 680-693. [CrossRef]

9. Tsonis, A.A.; Swanson, K.L.; Sugihara, G.; Tsonis, P.A. Climate Change and the Demise of Minoan Civilization. Clim. Past 2010, 6, 529-530. [CrossRef] 
10. Maliva, R.; Missimer, T. Ancient Water Management. In Arid Lands Water Evaluation and Management; Environmental Science and Engineering (Environmental Engineering); Springer: Berlin/Heidelberg, Germany, 2012.

11. Hellenistic Statistical Authority. 2011 Population-Housing Census. Available online: http://www.statistics. gr/en/2011-census-pop-hous (accessed on 6 October 2017).

12. Nikos, M.; $\triangle E Y A \Theta$, Santorini, Greece. Personal communication, 2016.

13. Weather-Atlas.com. Data Compiled from Hellenic National Meteorological Service. Available online: https:/ / www.weather-atlas.com/en/greece/santorini-climate (accessed on 6 October 2017).

14. Holst-Warhaft, G.; Steenhuis, T. (Eds.) Losing Paradise: The Water Crisis in the Mediterranean; Ashgate: Farnham, UK, 2010; Chapter 1; pp. 13-26.

15. Londra, P.A.; Theocharis, A.T.; Baltas, E.; Tsihrintzis, V.A. Optimal Sizing of Rainwater Harvesting Tanks for Domestic Use in Greece. Water Resour. Manag. 2015, 29, 4357-4377. [CrossRef]

16. United Nations Educational, Scientific and Cultural Organization. Available online: http:/ / en.unesco.org/events/ towards-global-network-water-museums-common-heritage-sustainable-future (accessed on 17 June 2017).

17. Kossida, M.; Tekidou, A.; Mimikou, M.A. Subsidies for Drinking Water Conservation in Cyprus. In Use of Economic Instruments in Water Policy; Lago, M., Mysiak, J., Gómez, C., Delacámara, G., Maziotis, A., Eds.; Global Issues in Water Policy; Springer: Cham, Switzerland, 2015; Volume 14.

18. Hakim, B.S. Greece: Sources from the Second Century B.C.E. to the Nineteenth Century C.E. In Mediterranean Urbanism; Springer: Dordrecht, The Netherlands, 2014.

19. Konstantina, T. Rainwater Harvesting in the Mediterranean Islands: Cases and Lessons Learned. In Proceedings of the RWH Knowledge Network Forum, Saint Lucia, Caribbean, 21-23 October 2014; p. 10. Available online: http:/ / www.caribbeanrainwaterharvestingtoolbox.com/Media/Print/RWH\%20in\% 20the\%20Mediterranean.pdf (accessed on 5 October 2017).

20. United Nations General Assembly. Development and International Economic Cooperation: Environment, Report of the World Commission on Environment and Development; A/42/427; Note by the Secretary-General; United Nations General Assembly: New York, NY, USA, 1987.

21. Nikos, M.; $\triangle \mathrm{EYA \Theta}$, Santorini, Greece. Municipal Water Drainage for the Water Resource Management of Thira. Personal communication, 2016.

22. Center for Responsible Travel. The Case for Responsible Travel: Trends and Statistics; Center for Responsible Travel: Washington, DC, USA, 2012; Volume 1.

23. Page, S.J.; Essexb, S.; Causevicc, S. Tourist attitudes towards water use in the developing world: A comparative analysis. Tour. Manag. Perspect. 2014, 10, 57-67. [CrossRef]

24. Papadimitriou, P.; Phoca, A. In Focus: Mykonos \& Santorini, Greece; HVS: Mineola, NY, USA, 2014; Available online: https:/ / www.hospitalitynet.org/file/152005392.pdf (accessed on 3 March 2017).

25. Voivontas, D.; Arampatzis, G.; Manoli, E.; Karavitis, C.; Assimacopoulos, D. Water supply modeling towards sustainable environmental management in small islands: The case of Paros, Greece. Desalination 2003, 156, 127-135. [CrossRef]

26. Nižić, M.K.; Ivanović, S.; Drpić, D. Challenges to Sustainable Development in Island Tourism. South East Eur. J. Econ. Bus. 2010, 5. [CrossRef]

27. Spilanis, I.; Vayanni, H. Sustainable Tourism: Utopia or Necessity? The Role of New Forms of Tourism in the Aegean Islands. J. Responsib. Tour. 2003, 407, 1-23.

28. Tipping, D.C. The Underlying Value of Wholesome and Clean Water; Australian Competition and Consumer Commission (ACCC): Melbourne, Australia, 2008; p. 1.

29. Doria, M.D.F.; Pidgeon, N.; Hunter, P.R. Perceptions of drinking water quality and risk and its effect on behaviour: A cross-national study. Sci. Total. Environ. 2009, 407, 5455-5464. [CrossRef] [PubMed]

30. Fielding, K.S.; Gardner, J.; Leviston, Z.; Price, J. Comparing public perceptions of alternative water sources for potable use: The case of rainwater, stormwater, desalinated water, and recycled water. Water Resour. Manag. 2015, 29, 4501-4518. [CrossRef]

31. Shomar, B.; Hawari, J. Desalinated drinking water in the GCC countries-The need to address consumer perceptions. Environ. Res. 2017, 158, 203-211. [CrossRef] [PubMed]

32. Dolnicar, S.; Hurlimann, A. Drinking water from alternative water sources: Differences in beliefs, social norms and factors of perceived behavioural control across eight Australian locations. Water Sci. Technol. 2009, 60, 1433. [CrossRef] [PubMed] 
33. Alegre, H.; Baptista, J.M.; Cabrera, E.; Cubrillo, F.; Duarte, P. Performance Indicators for Water Services, 3rd ed.; IWA Publishing: London, UK, 2016.

34. Mantoglou, A.; Giannoulopoulos, P. Sustainable Yield of Coastal Aquifers: Simulation, Optimization and Application to Santorini Island. In Proceedings of the Protection and Restoration of the Environment VII Conference, Mykonos, Greece, 28 June-1 July 2004.

35. Gratziou, M.; Andreadaki, M.; Tsalkatidou, M. Water demand and rates policy in provincial cities in Greece. Eur. Water 2006, 15/16, 33-44.

36. Okun, D.A. Water Reclamation and Unrestricted Nonpotable Reuse: A New Tool in Urban Water Management. Annu. Rev. Public Heal. 2000, 21, 223-245. [CrossRef] [PubMed]

37. Drewes, J.E.; Khan, S.J. Water Reuse in Drinking Water Augmentation. In Water Quality E Treatment: A Handbook on Drinking Water; Edzwald, J.K., Ed.; McGraw-Hill: New York, NY, USA, 2011.

38. Angelakis, A.N.; Gikas, P. Water Reuse: Overview of current practices and trends in the World with emphasis in EU. Water Util. J. 2014, 6, 67-78.

39. Drewes, J.E.; Horstmeyer, N. Recent Developments in Potable Reuse. Advanced Treatment Technologies for Urban Wastewater Reuse. In Handbook of Environmental Chemistry; Fatta-Kassinos, D., Dionysios, D., Kummerer, K., Eds.; Springer International Publishing: Cham, Switzerland, 2016; Volume 45, pp. 269-290.

40. Campisano, A.; Butler, D.; Ward, S.; Burns, M.J.; Friedler, E.; DeBusk, K.; Fisher-Jeffes, L.N.; Ghisi, E.; Rahman, A.; Furumai, H.; et al. Urban rainwater harvesting systems: Research, implementation and future perspectives. Water Res. 2017, 115, 195-209. [CrossRef] [PubMed]

41. World Wildlife Fund. Available online: http://mediterranean.panda.org/?2711/Every-drop-countstowards-sustainable-water-use-in-Greece (accessed on 12 July 2017).

42. Laureano, P. Ancient water techniques for proper management of Mediterranean ecosystems. Water Sci. Technol. Water Supply 2007, 7, 237-244. [CrossRef]

43. World Bank. Available online: http://treasury.worldbank.org/cmd/htm/WorldBankGreenBonds.html (accessed on 23 July 2017).

44. TEMAK. Available online: www.temak.gr/site/thira (accessed on 13 July 2017).

(C) 2017 by the authors. Licensee MDPI, Basel, Switzerland. This article is an open access article distributed under the terms and conditions of the Creative Commons Attribution (CC BY) license (http:/ / creativecommons.org/licenses/by/4.0/). 